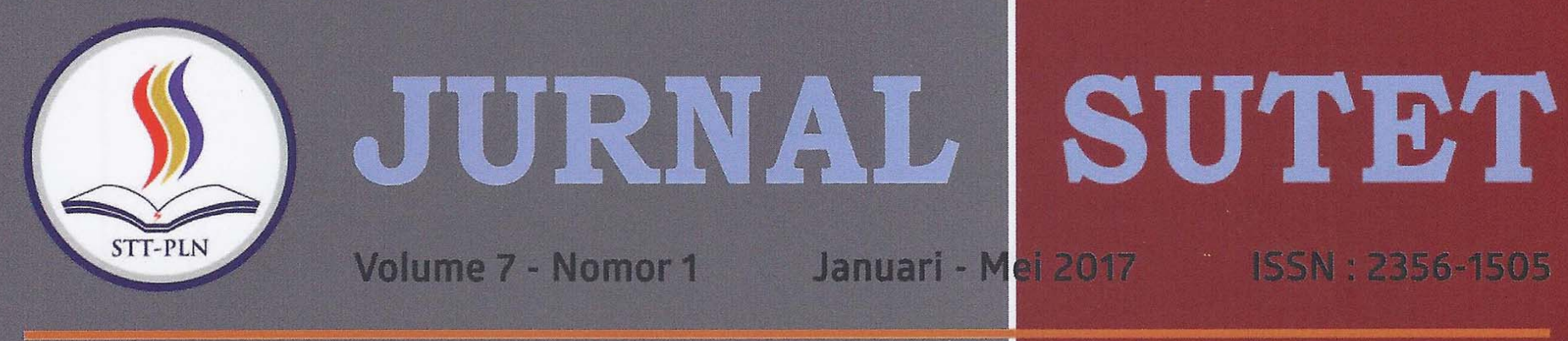

DESAIN SISTEM ALARM MOBIL BERBASIS SMS

Erlina; Hendrianto Husada; Bambang Tri Atmodjo

KELAYAKAN PENGGUNAAN PENDINGIN THERMOELEKTRIK UNTUK PENGHEMATAN DAYA LISTRIK PADA BASE TRANSCEIVER

Sunaryo; Uno Bintang Sudibyo; Supriadi Legino

WITRICITY (WIRELESS ELECTRICITY)

Aas Wasri Hasanah; Oktaria Handayani

CONCEPTUAL DESIGN FOR MITIGATING HARMONIC DISTORTION ON ESP INSTALLATION: CASE STUDY IN KAJI SEMOGA FIELD, MEDCO E\&P INDONESIA

Sandy Suryakusuma; Suprapto Atmowiranto; Dadang Darmawan

RANCANGAN RANGKAIAN ANTI BOUNCING UNTUK RANGKAIAN DIGITAL

Tasdik Darmana

STUDI POWER WHEELING DIKAWASAN INDUSTRI JABABEKA

Bimo Brillianta; Uno Bintang Sudibyo; Wildan Aripin

PEMASANGAN ARRESTER DAN ARCING HORN PADA PENGHANTAR BERISOLASI DI SUTM $20 \mathrm{kV}$ Christine Widyastuti; Andi Makkulau

PENGELOLAAN EMISI GAS LANDFILL (BIOGAS) SEBAGAI ENERGI TERBARUKAN Isworo Pujotomo; Muchamad Nur Qosim

DISAIN SISTEM PENTANAHAN PROTEKSI PETIR SISTEM MULTIPLE VERTICAL ELECTRODES PADA TERMINAL LAWE-LAWE - PERTAMINA DHP

Ibnu Hajar

ANALISA DCS (DISTRIBUTED CONTROL SYSTEM) PADA PROSES POLIMERISASI

Syarif Hidayat; Irsyadi Akbar Jay

PENGEMBANGAN TEKNOLOGI SISTEM SMART MICROGRID DI SEKOLAH TINGGI TEKNIK PLN Heri Suyanto; Agung Hariyanto

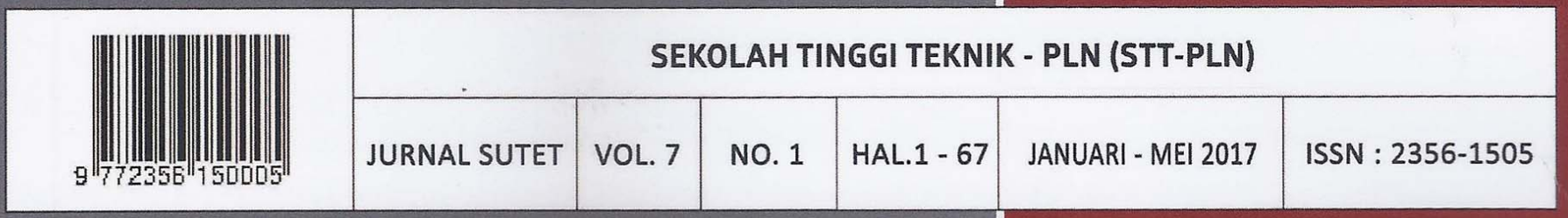




\title{
PENGEMBANGAN TEKNOLOGI SISTEM SMART MICROGRID DI SEKOLAH TINGGI TEKNIK PLN
}

\author{
${ }^{1}$ Heri Suyanto, ${ }^{2}$ Agung Hariyanto \\ Teknik Elektro, Sekolah Tinggi Teknik PLN, Jakarta, Indonesia \\ Email : ${ }^{1}$ heri.suyanto@yahoo.com, ${ }^{2}$ agung.hariyanto@gmail.com
}

\begin{abstract}
Nowadays application of new and renewable energy as power plan renewable energy resources as power plant resource more and more increased. High penetration of renewable energy into the grid will influence the quality and reliability of the electricity system, due to the intermittent characteristic of renewable energy resources. The smart grid or microgrid technology has the ability to deal with this intermittent characteristic especially while these renewable energy resources integrated to grid in large scale, so its can improve the reliability and efficiency of that grid. We plan to implementation of smart microgrid system at School High Tehnik of PLN as a pilot project. Before the pilot project design, the feasibility study must be conducted. In this feasibility study, the renewable energy resources and load characteristic at the site will be measure. Then the technical aspect of this feasibility study will be analyze.This paper explained the analysis of thus feasibility study.
\end{abstract}

Keywords : Smart Microgrid, Renewable Energy

\begin{abstract}
Abstrak : Saat ini pemanfaatan Energi Baru Terbarukan (EBT) sebagai sumber pembangkit tenaga listrik semakin meningkat. Penetrasi sumber Energi Baru Terbarukan secara besar - besaran akan sangat berpengaruh pada kualitas dan Keandalan system tenaga listrik, karena sifat dari sumber Energi Baru Terbarukan yang intermittent, Untuk itu perlu di kembangkan suatu teknologi yang dapat mengkompensasi intermittent sumber energy tersebut. Teknologi smart grid/microgrid merupakan teknologi yang mampu mengkompensasi ketidakstabilan dari suplai energy terbarukan kedalam grid dalam skala besar, sehingga akan meningkatkan keandalan dan efisiensi dari jaringan listrik tersebut. Sebagai pilot project dari sistem smart microgrid yang direncanakan di Sekolah Tinggi Teknik PLN. Untuk itu di perlu di lakukan studi kelayakan terhadap aplikasi pilot project tersebut. Dalam Studi kelayakan ini dilakukan pengukuran potensi Energi Baru Terbarukan dan profile beban untuk kemudian dianlisis kelayakan teknisnya. Penelitian ini menjelaskan tentang analisis dari studi kelayakan tersebut.
\end{abstract}

Kata Kunci : Smart Microgrid, Energi Baru Terbarukan,

\section{PENDAHULUAN}

Kondisi ketenagalistrikan di Indonesia saat ini masih kurang memadai, dimana rasio elektrifikasi masih rendah yaitu $87 \%$ per Oktober 2015 (PT. PLN Persero). Hal ini menunjukkan bahwa akses masyarakat terhadap energy masih terbatas. Begitu juga dengan pengembangan infrastruktur energi di daerah perdesaan/terpencil dan pulau-pulau terluar pada umumnya belum mendapatkan akses energi yang memadai. Ketergantungan industri ketenagalistrikan terhadap energi tersebut semakin terbatas. Pemanfaatan energi baru terbarukan dan implementasi konservasi energi juga belum optimal.

Sebagai salah satu cara untuk memenuhi kebutuhan masyarakat akan energi listrik dan sesuai dengan kebijakan - kebijakan pemerintah Indonesia, maka beberapa tahun belakangan ini sudah mulai banyak dikembangkan sistem pembangkit listrik dan Energi Baru Terbarukan (EBT). Karena sifat dari Energi Baru Terbarukan yang intermittent, maka dibutuhkan suatu sistem yang dapat mengatasi masalah tersebut. Sistem 
smart microgrid atau smart grid adalah salah satu teknologi yang dapat secara efektif dan effisien mengatasi integrasi Energi Baru Terbarukan ke dalam system kelistrikan dalam skala besar.

Sejak tahun 2015 STT PLN telah melakukan penelitian smart microgrid, dengan tahapan : studi potensi (2015) dan perancangan model smart microgrid skala labotaroium (2016), Sebagai pengembangan dari Model smart microgrid dan untuk aplikasinya di lapangan, maka sebagai langkah awal dari penerapan di rencanakan untuk membangun pilot project sistem smart microgrid skala laboratorium di STT PLN Tahun 2017.

\section{TINJAUAN PUSTAKA}

Penelitian dan pengembangan energi terbarukan khususnya Pembangkit Tenaga Listrik Surya berbasis teknologi smart-grid telah tercantum pada RIP STT PLN 2013 - 2018. Salah satu strategi untuk pemenuhan kebutuhan energi listrik adalah dengan memanfaatan sumber potensi Energi Baru Terbarukan (EBT) yang ada di lokasi setempat, agar dapat mengurangi biaya transmisi dan distribusi. Potensi Energi Terbarukan (ET) di daerah setempat dimanfaatkan untuk pemenuhan kebutuhan energi listrik di daerah tersebut. $\mathrm{Hal}$ ini akan menyebabkan meningkatnya penetrasi energi terbarukan dalam jaringan listrik. Penentrasi yang tinggi dari sumber energi terbarukan dapat menyebabkan permasalahan dalam stabilitas, keandalan dan kualitas daya pada grid utama. Smart microgrid menjadi elemen kunci dari jaringan listrik di masa depan dimanapenerapan penetrasi yang tinggi dari energi terbarukan tidak mempengaruhi atau mengganggu kualitas daya dari jaringan listrik.

Suatu sistem smart microgrid dapat diartikan sebagai suatu sistem ketenagalistrikan yang terdiri dari beberapa Distributed Generation (DG) yang biasanya bersumber dari EBT, seperti panel photovoltaic, wind turbine, mikroturbin, dengan penambahan suatu sistem penyimpanan, pengontrolan beban, dan suatu sistem pengaturan energi (Energy Management System - EMS).
EMS memungkinkan sistem smart microgrid untuk mengambil keputusan sendiri terbebas dari grid saat sistem beroperasi pada mode standalone (islanding). Sistem smart microgrid ini dapat beroperasi delam dua mode operasi, yaitu On-Grid / Grid-connected dan Off-Grid / Standalone / Islanding. Mode operasi Off-Grid/Standalone/ Islanding adalah saat circuit breaker mengisolasi sistem dari grid utama (PLN), sehingga peralatan pembangkit, penyimpanan, pengatur beban, pengatur kualitas daya dan pengatur pengoperasian sistem lainnya diterapkan hanya pada system smart microgrid. Pada mode OffGrid beban disuplai dari daya listrik yang dihasilkan oleh DG, Diesel Generator (jika ada sebagai cadangan) dan Baterai. Pada mode on-grid/grid connected, sistem smart microgrid juga merupakan beban yang dapat dikontrol, atau daya yang dibangkitkan dari grid adalah sumber energi cadangan/tambahan. Pada mode On-Grid/Grid Connected ini beban disuplai oleh DG, grid (sebagai cadangan) dan Baterai.

\section{METODE PENELITIAN}

Hasil yang diharapkan dari program penelitian ini adalah adanya sinergi yang saling menguntungkan dan saling menunjang antara perguruan tinggi (STT PLN) dan mitra industri untuk menghasilkan produk pembangkit listrik hybrid yang dirancang dan dibuat dalam suatu struktur jaringan cerdas mikro (distributedsmart micro-gid), dengan didukung teknologi yang tinggi, sehingga dapat dioperasikan didaerah/pulau terpencil untuk memenuhi kebutuhan perumahan dan juga menunjang operasi menjaga keutuhan wilayah NKRI.

Metodologi dan tahapan riset yang akan digunakan sebagai berikut :

a. Melakukan pengukuran potensi Energi Baru Terbarukan, dalam hal ini energi angin dan matahari di Lingkungan kampus Sekolah Tinggi Teknik PLN.

b. Analisis data intensitas panas matahari pada daerah-daerah yang akan dituju (daerah/pulau terpencil), 
mengacu pada data dari BMKG dan Lapan serta instansi lain.

c. Melakukan pengukuran karekteristik beban di lokasi rencana penempatan sistem smart micro grid.

d. Melakukan analisis terhadap data potensi dan karekteristik beban.

e. Melakukan analisis kelayakan teknis dari sistem smart micro grid seperti spesifikasi teknis solar cell, dan menentukan sistem kontrol daya listrik berbasis "power electronics" yang akan digunakan berdasarkan kajian literature.

\section{HASIL DAN PEMBAHASAN}

Sekolah Tinggi Teknik PLN terletak di Menara PLN, Jl. Lingkar Luar Barat, Duri Kosambi, Cengkareng, Duri Kosambi, Cengkareng, Kota Jakarta Barat, DKI Jakarta 11750. Pada sistem beban listrik di Gedung utama Kampus sebesar $100 \mathrm{KW}$, dan beban di Laboratorium STT PLN sebesar $15 \mathrm{KW}$.

Setelah melakukan diskusi dengan dosen - dosen dan mahasiswa Sekolah Tinggi Teknik PLN dan dengan melakukan pengamatan langsung di lokasi maka ditetapkan bahwa project sistem smart microgrid akan dibangun Gedung Laboratorium tepat pada Gedung Research and Training Center For Renewble Energy Power System. Dengan adanya Pembangkitan Listrik Tenaga Surya di Laboratorium ini akan mengurangi tagihan listrik dari PT. PLN.

Perencanaan yang akan dibangun Energi Baru dan Terbarukan STT PLN sebagai berikut sesuai dengan Gambar 1 antara lain sebagai berikut :

1. Pembangkit Listrik Tenaga Surya (PLTS) kapasitas $14,5 \mathrm{kWp}$

2. Pembangkit Listrik Tenaga Bayu/ angin (PLTB) kapasitas $20 \mathrm{~kW}$

3. Pembangkit Listrik Biomassa 16 kVA yang terdiri :

- Gasifer PLTsampah 14 kVA

- Digester PLTsampah 2 kVA

4. Dengan Sistem KWH meter Eksim (Ekspor dan Impor) dari PT. PLN (Persero) dan Baterai

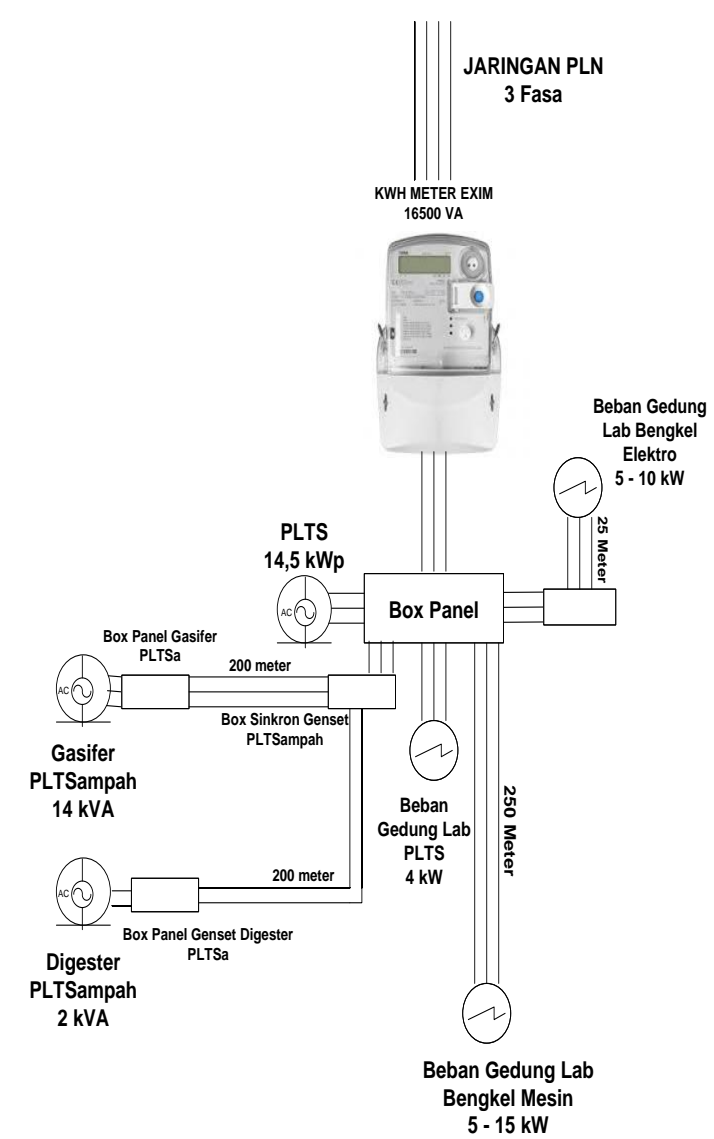

Gambar 1. Sistem Perencanaan Sistem Smartmicrogrid STT PLN.

Berikut gambar rancangan Intalasi PLTS yang sudah terpasang dengan kapasitas $14.5 \mathrm{~kW}$ dengan sistem smart microgrid On Grid dan Off Grid.

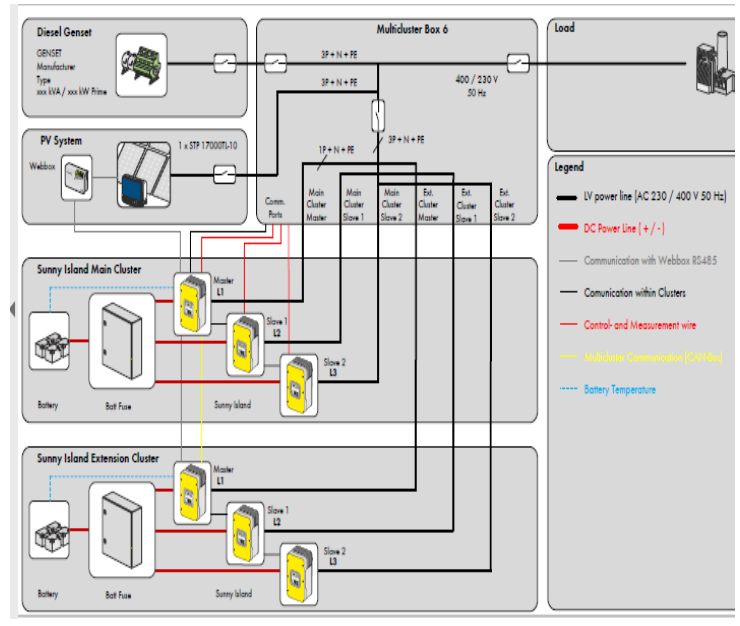

Gambar 2. Rancangan Sistem Smart Microgrid system offgrid di STT PLN 


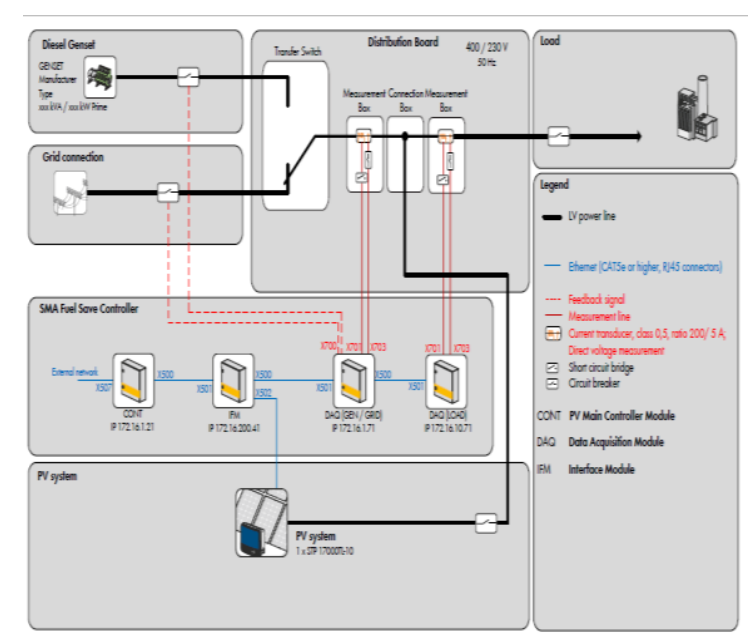

Gambar 3 Rancangan Sistem Smart Microgrid system ongrid di STT PLN

Pembangkit Tenaga Surya yang kita pasang Kapasitas $17 \mathrm{~kW} /$ peak sudah ter Integrasi KWH Meter Exim Ekspor dan Impor dan sudah dipasang sistem monitoring yang teknologi canggih. Perancangan ini dibuat sebagai Penelitian dengan mengenal teknologi energy baru dan terbarukan khususnya Pembangkit Tenaga Surya dan sebagai mengurangan pemakain listrik PT. PLN (Persero) sehingga sehingga tagihan listrik turun. Berikut Gambar kurva pada system monitoring yang dihasilkan listrik PLTS.

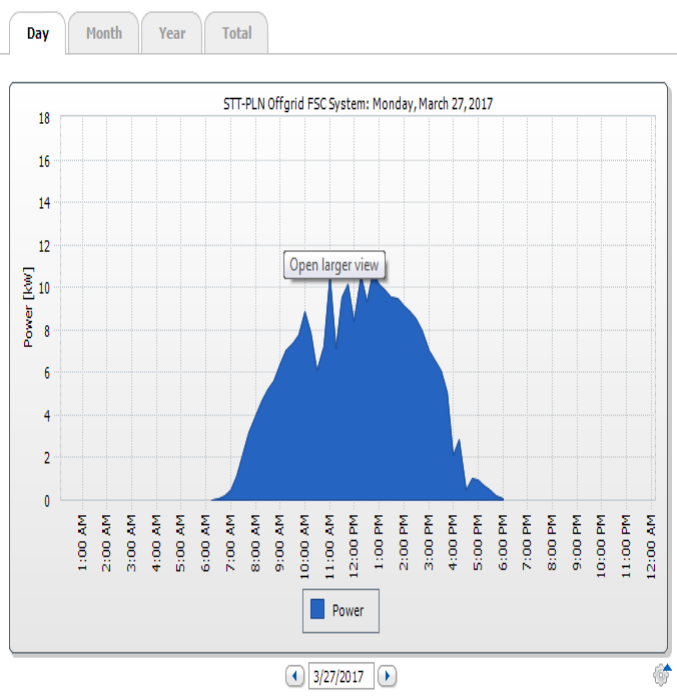

Gambar 4. Kurva Listrik PLTS dalam Satuan Harian

Dari kurva tersebut menunjukkan puncak maksimal pada jam 11.00 sampai 14.00 mencapai $10 \mathrm{~kW}$ sehingga satu bisa mencapai $70 \mathrm{~kW}$ pada posisi hasil
Maksimum Harian dan Rata-rata Harian mencapai $40 \mathrm{~kW}$.

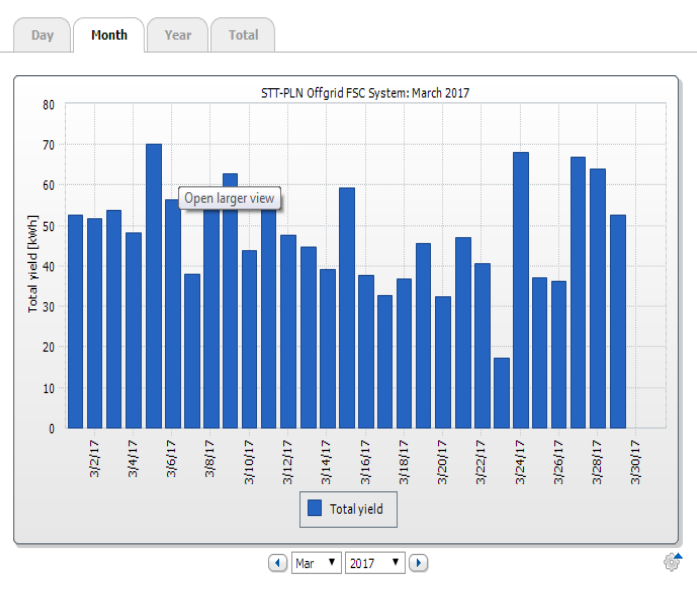

Gambar 5. Kurva Listrik PLTS dalam Satuan Bulanan

Dari gambar kurva Listrik PLTS dalam satuan Bulanan listrik yang dihasilkan dari Pembangkit Listrik Tenaga Surya bisa mencapai 1.4 MWh. dan Pembangkit Listrik Biomassa sedang dalam tahap perancangan.

Untuk Pembangkit Listrik Tenaga Bayu / angin dan Pembangkit Listrik Biomassa dalam kondisi tahap perancangan yang akan di bangun.

Project Smart Microgrid ini akan diaplikasikan dipakai sebagai Penelitian dan Pembelajaran Tentang Energi Baru dan Terbarukan Di Laboratorium Research and Training Center For Renewble Energy Power System STT PLN.

\section{KESIMPULAN}

1. Dari analisis yang dilakukan terhadap aspek teknis studi kelayakan penerapan Project Sistem Smart Microgrid di Sekolah Tinggi Teknik PLN layak dengan ketersedian potensi cukup tinggi dan area pemasangan peralatan sesuai yang kita harapkan.

2. Project Sistem Smart Microgrid di Sekolah Tinggi Teknik PLN ditempatkan Laboratorium Research and Training Center For Renewble Energy Power Sistem STT PLN 
sebagai Penelitian Teknologi Energi Baru dan Terbarukan dan sebagai pengurangan pemakaian listrik dari pihak PT. PLN.

3. Perencanaan sistem smartmicrogrid yang akan dibangun Energi Baru dan Terbarukan STT PLN terdiri dari PLTS kapasitas $14.5 \mathrm{kWp}$, PLTB kapasitas $20 \mathrm{~kW}$, PLTbiomassa dengan 14 kVA Gasifer PLTS sampah maupun Digester PLTS sampah 2 kVA) dan Baterai.

\section{REFERENSI}

[1] CERTS Microgrid Symposium, Northern Power Systems

[2] Clarke,S.,2003. "Electricity Generation Using Small Wind Turbines At Your Home Or Farm", Fact Sheet,

[3] C.W. Gellings,2009. " The Smart Grid - Enabling Energy Efficiency and Demand Response", CRC Press,

[4] J. B. (Secretary of U. S. D. of C. P. D.G. (Director of N. I. of S. and Technology).2012, NIST Framework and Roadmap for Smart Grid Interoperability Standards

NISTSpecial Publication 1108R2 NIST Framework and Roadmap for Smart Grid Interoperability Standards, NIST Speci. Energy Independence and Security Act of 2007.

[5] Jay Stuller, "An Electric Revolution", Galvin Electricity Initiative
[6] Anonim. 2010. IEC Smart Grid Standardization Roadmap, Prepared by SMB Smart Grid Strategic Group (SG3) June; Edition 1.0

[7] "The Smart Grid: Coming Of Age", Electric Power Research Institute Journal, EPRI,Inc. 2009.

[8] Kurt Yeager,.2010. "The Microgrid Revolution",

[9] Anonim,. 2009. Smart Houses interacting with Smart Grids to achieve next generation efficiency and sustainability, Dr. Anke Weidlich, SAP Research 11.02.

[10] R. Ramakumar,2012. "Integrated Renewable Energy System - Micro Grid (IRES-MG) For Sustainable Development", ICSUNIDO, Trieste, Italy,

[11] T.Nakata, K. Kubo and A. Lamont, "Design For Renewable Energy System With Application To Rural Area In Japan", white paper. 